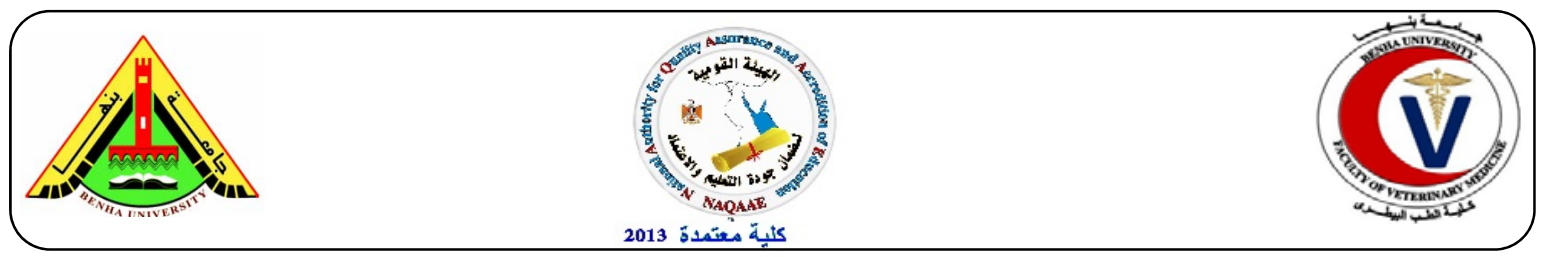

\title{
Evaluation of pulmonary function tests with hemato-biochemical alterations in Boer goats affected with klebsiella pneumoniae.
}

\author{
Ghanem, M.M.1, Yousif, H.M.2, Abd El-Ghany, A.H.1, Abd El-Raof, Y.M.1, El-Attar, H.M.1 \\ ${ }^{1}$ Animal Medicine Department*, Faculty of Veterinary Medicine, Benha University. ${ }^{2}$ Veterinary \\ Medicine Directorate of Kalubia. *e-mail: mohamed.ghanem@fvtm.bu.edu.eg
}

\begin{abstract}
A B S T R A C T
In this study twenty Boer goats (10 with pneumonia and 10 apparently healthy) were selected from 150 Boer goats that were recently transported from the Upper Egypt to Moshtohor farm. Nasal swabs and trans-tracheal aspiration were taken for bacteriological examination as well as whole blood and serum samples were collected for evaluation of pulmonary function tests, hematological and biochemical alterations in pneumonic Boer goats compared with apparently healthy ones. Bacteriological examination and PCR of nasal swabs and trans-tracheal aspiration revealed klebsiella pneumoniae. The results revealed that, significant $(P<0.05)$ decrease in RBCs, Hb and PCV in pneumonic animals than that of healthy one. The significant $(P<0.05)$ increase in WBCs and neutrophils were detected as well as significant $(P<0.05)$ decrease in lymphocyte count. Pulmonary function tests revealed significant $(P<0.05)$ reduction in blood $\mathrm{pH}$ and $\mathrm{PO}_{2}$ while there was a significant $(P<0.05)$ increase in $P \mathrm{CO}_{2}, \mathrm{tCO}_{2}$ and BE. Serum biochemical revealed significant $(P<0.05)$ increase in globulin, IgG, IgA, AST, ALT, urea, creatinine, $\mathrm{P}$ and $\mathrm{K}$, while total protein, albumin, $\mathrm{Fe}, \mathrm{Mg}, \mathrm{Ca}$ and $\mathrm{Cl}$ were significantly decreased. Pulmonary function tests and hematobiochemical alterations could be used as a diagnostic indicators for pneumonia in Boer goats.
\end{abstract}

KEYWARDS: Pneumonia, Hematology, Biochemicals, Pulmonary functions, Klebsiella. (http://www.bvmj.bu.edu.eg)

(BVMJ-29(1):53-62, 2015)

\section{INTRODUCTION}

B oer goats have an interest of meat goat producers due to claims that they are fast growers, hardy and adaptable, resistant to diseases, fertile and produce meat of high quality (Erasmus, 2000). Pneumonia refers to the inflammation of the pulmonary parenchyma that might be accompanied by the inflammation of bronchioles and often pleurisy and, it is characterized by respiratory embarrassment or sometimes toxemia. Upper respiratory infections are accompanied with respiratory abnormalities and very often descend producing pneumonia (Autio et al., 2007 and Ackermann et al., 2010). It is regarded as a disease complex, involving interactions between host (immunological and physiological), and multiple infectious agents (viral and bacterial) with environmental factors (Kathryn, 2006 and Kumar et al., 2014). When a certain threshold dose of microorganisms, host susceptibility and non-specific defense mechanisms are reached, lung defense mechanisms are compromised allowing disease to occur (Bruere et al., 2002). Klebsiella pneumoniae is a common opportunistic pathogen of communityacquired and nosocomial infections (Fang et al., 2004). Klebsiella pneumoniae causing pneumonia, while it produces virulence factors such as smooth lipopolysaccharide (LPS with O antigen), pili for adhesion to host cells, capsules (K antigen) that are anti-phagocytic, siderophores that aid the bacterium in its competition with the host for iron uptake 
(Izquierdo et al., 2003). Bacteriologically, Klebsiella pneumoniae is Gram negative bacteria, facultative anaerobic, non-motile, rod-shaped, with a prominent polysaccharide capsule. This capsule encases the entire cell surface, accounts for the large appearance of the organism on Gram stain and provides resistance against many host defense mechanisms (Loschko et al., 2011). The main clinical signs of pneumonia are rise of body temperature, depression, increased eye and nasal discharge, loss of appetite and acceleration of respiration. Exaggerated vesicular sound and moist rales with frictional sound may be heard by auscultation (Zaitoun, 2001 and Zaghawa et al., 2010). Since the gaseous exchange is the main pulmonary function, respiratory acidosis, with increased $\mathrm{PCO}_{2}$ and $\mathrm{HCO}_{3}$ and decreased $\mathrm{PO}_{2}$ is expected with impaired pulmonary function (Smith and Sherman, 2009 and Tanritanir et al., 2010). The serum biochemical change of pneumonic goat indicates significantly lower in $\mathrm{Ca}$ and $\mathrm{Mg}$ levels. The concentration of inorganic phosphorus in infected goats was significantly increased in comparison with the healthy goats (Sadeghian et al., 2011). The elevated serum enzymatic activity of ALT and AST in the diseased pneumonic sheep. The results of serum protein electrophoretic fractionation profile showed that there was a significant decreases in serum concentration of albumin but serum levels of gamma ( $\gamma$-Glob) globulins demonstrated a significant increase (Saleh and Allam, 2014). Since very few studies were conducted on pneumonia in Boer goats, this work aims to investigate the clinical picture and evaluate the hemato-biochemical alterations and pulmonary function tests with isolation and identification of the causative agents of pneumonia in Boer goats.

\section{MATERIALS AND METHODS}

\subsection{Field design:}

The present study was carried out on 150 Boer goats in Moshtohor private farm. The goats were recently transported from Upper Egypt to Moshtohor farm (40 Km north Cairo). Shortly after transportation, 50 out of 150 Boer goats, suffered from clinical signs of pneumonia. Ten of pneumonic goats were used as diseased group and 10 apparently healthy Boer goats were selected from the herd used as a control group.

\subsection{Clinical examination}

The Boer goats were subjected to clinical examination and all clinical signs were recorded.

\subsection{Isolation and identification of causative bacteria}

The method of collecting samples of transtracheal aspiration resembled that for broncho-alveolar lavage (BAL) samples with some modifications. A tracheal wash catheter was passed through the endotracheal tube to the bronchial bifurcation and begin to aspirate the transtracheal contents using $100 \mathrm{ml}$ phosphate buffered saline (PBS). Gentle, negative pressure was applied to the catheter, and then the endotracheal tube was removed (Smith and Sherman, 2009). The collected samples were submitted for microbiological examination with nasal swabs samples that inoculated in nutrient broth for activation of the microorganism at $37^{\circ} \mathrm{C}$ for 24 hours. A sterile lopfull from the broth with activated micro-organism was directly sub-cultured on MacConkey's and blood agar. Plate readings occurred at $24 \mathrm{hrs}$ and $48 \mathrm{hrs}$. The isolates recovered were sub-cultured and further identified using colony morphology, Gram stain and biochemical tests (Carter, 1990). The identification of suspected bacteria colonies was achieved by observation of colonial morphology under microscopy and the use of some biochemical tests: hemolysis, motility, indole formation, glucose, lactose, methyl red, voges proskeur and citrate utilization. Assay for biochemical properties of the bacteria isolates were conducted according 
to MacFaddin's method (MacFaddin, 2000).

\subsection{DNA Extraction and Polymerase Chain Reaction (PCR):}

The sample of sterile lopfull from the isolated colonies of MacConkey agar were introduced for identification by PCR. DNA was extracted using genomic DNA extraction kit/Geneaid according to the manufacture protocol (according to QIAamp DNA mini kit instructions).

Oligonucleotide primers used in cPCR: One pair of primers were used which are specific for gyr A gene of Klebsiella according to (Brisse and Verhoef, 2001). They have specific sequence and amplify a specific product of $441 \mathrm{bp}$ length, the forward primer was 3' CGC GTA CTA TAC GCC ATG AAC GTA 5', and the reverse primer was 5' ACC GTT GAT CAC TTC GGT CAG G 3'. DNA Molecular weight marker: Gel Pilot 100 bp ladder (cat. no. 239035) supplied from QIAGEN. Number of bands: 6 Size range: $100-600 \mathrm{bp}$. The temperature and time conditions of the steps of PCR modification was done according to Brisse and Verhoef (2001) using Emerald Amp GT PCR mastermix (Takara) kit, as follow: Gene gyr A. Primary denaturation $\left(95^{\circ} \mathrm{C}\right)$ 15 min. Secondary denaturation $\left(95^{\circ} \mathrm{C}\right) 1$ min. Annealing $\left(55^{\circ} \mathrm{C}\right) 1 \mathrm{~min}$. Extension $\left(72^{\circ} \mathrm{C}\right) 1 \mathrm{~min}$. Number of cycling 35 . Final extension $\left(72^{\circ} \mathrm{C}\right) 10 \mathrm{~min}$.

\subsection{Hematological examination}

Whole blood samples were collected from 10 diseased and 10 healthy Boer goats for determination of RBCs count, hemoglobin (Hb), PCV\%, total leukocytic count (WBCs) and differential leukocytic counts. These parameters were measured by hematology analyzer (Feldman et al., 2000).

\subsection{Pulmonary function tests}

Anaerobically the jugular venous blood samples were drawn from each animal into $3 \mathrm{ml}$ plastic syringes (containing freezedried lithium heparin). Immediately after vein-puncture, the tip of the needle was sealed with a rubber stopper in order to prevent gas from moving in or out of it. The samples were placed in a bed of crushed ice, taken immediately to the laboratory for analysis. The blood samples were analyzed for $\mathrm{pH}$, partial pressure of carbone dioxide $\left(\mathrm{PCO}_{2}\right)$, partial pressure of oxygen $\left(\mathrm{PO}_{2}\right)$, bicarbonate $\left(\mathrm{HCO}_{3}\right)$, total carbon dioxide content $\left(\mathrm{tCo}_{2}\right)$ and base excess (BE), using blood gas analyzer (Hussein and Aamer 2013).

\subsection{Biochemical examination}

Special kits (Stain Bio Company) were used for spectrophotometric determination of total protein, albumin, ALT, AST, creatinine, urea, $\mathrm{Ca}, \mathrm{P}, \mathrm{Na}, \mathrm{K}, \mathrm{Cl}$, iron, $\mathrm{Mg}$. Serum immunoglobulin IgG and IgA were determined by direct ELISA as previously recorded (Henrik, 1994). Albumin and globulins were separated by cellulose acetate electrophoresis using Helena system (Helena France) (Batavani et al, 2006).

\subsection{Statistical analysis}

The mean values in diseased group were compared to control group using student's T-test. The values were considered significant at $P<0.05$.

\section{RESULTS}

\subsection{The clinical signs:}

The common clinical signs were shallow rapid respiration $(41.5 \pm 5.25$ breath $/ \mathrm{min})$, dyspnea, nasal discharge (purulent and mucopurulent may be tinged with blood), fever $\left(40.5 \pm 0.4{ }^{\circ} \mathrm{C}\right)$, redness of ocular mucous membrane and conjunctiva, crusts around nasal orifice, exaggerated heart rate (128 $\pm 13 \mathrm{beat} / \mathrm{min})$, moist painful cough and dry cough, depression and anorexia. Lung auscultation showed loud wheezing, crackling sound, moist rales and exaggerated vesicular sound compared with apparently healthy Boer goat (Fig, 1-6).

\subsection{Isolation and identification of causative agent:}

The isolation of the causative agent from the nasal swabs and trans-tracheal 
aspiration were inoculated on specific media (MacConkey and Blood agar), revealed only presence of pink coloration colonies on the MacConkey agar media. The Gram staining revealed Gram negative (-ve), rod shaped, non-motile. The identification of the causative bacterial agent that appeared on MacConkey agar media was further processed by using the specific biochemical tests that revealed the glucose and lactose fermentation with gas production, Indole (no indole ring formation) and Methyl red tests (yellowish color formation) are negative (-ve), in which Citrate utilization test (blue color) and Voges proskour tests (pink color) are positive $(+v e)$ which might confirm klebsiella pneumoniae.

\subsection{The result of PCR:}

The confirmatory identification of the gyr A gene of Klebsiella by using the PCR identification revealed positive $(+\mathrm{ve})$ result of klebsiella in the three samples including nasal swabs, transtracheal aspiration and lung. The length of amplified product was 441 bps (Fig. 7).

\subsection{Hematological changes:}

The hematological evaluation of the pneumonic animals revealed significant $(P<0.05)$ decrease in RBCs count $\left(10^{6} / \mu 1\right)$, $\mathrm{Hb}(\mathrm{gm} / \mathrm{dl})$ and $\mathrm{PCV}(\%)$, while there was a significant $(P<0.05)$ increase in both WBCs count $\left(10^{3} / \mu \mathrm{l}\right)$ and neutrophils count with a significant $(P<0.05) \quad$ decrease in lymphocytes count. No significant changes in both monocytes and eosinophil counts were observed (Table 1).

\subsection{Pulmonary function tests:}

The pulmonary function tests showed significant $(\mathrm{P}<0.05)$ reduction in $\mathrm{pH}$ and $\mathrm{PO}_{2}$ with a significant $(P<0.05)$ increase in $\mathrm{PCO}_{2}, \mathrm{HCO}_{3}, \mathrm{tCO}_{2}$ and $\mathrm{BE}$, compared to control group (Table 2).

\subsection{The serum biochemical changes:}

The serum biochemical analysis of the pneumonic Boer goats revealed significant
$(P<0.05)$ decrease in total protein, albumin and $\mathrm{A} / \mathrm{G}$ ratio, with significant $(P<0.05)$ increase in globulin level. There was a significant $(P<0.05)$ increase in ALT, AST, urea and creatinine levels compared to healthy animals (Table 3 ). There was a significant $(P<0.05)$ increase in $\mathrm{IgG}$ and IgA levels. The protein electrophoresis analysis showed a significant $(P<0.05)$ increase in gamma $(\gamma)$ globulin with a nonsignificant changes in alph $(\alpha)-1$ - globulin, alph $(\alpha)$-2- globulin and beta $(\beta)$ globulin compared to healthy Boer goats (Table 4). Serum minerals analysis showed a significant $(P<0.05)$ decrease in $\mathrm{Ca}, \mathrm{Cl}, \mathrm{Mg}$ and $\mathrm{Fe}$, while there was a significant $(P<0.05)$ increase in $\mathrm{P}$ and $\mathrm{K}$ and no significant changes in $\mathrm{Na}$, compared to healthy Boer goats (Table 5).

\section{DISCUSSION}

Klebsiella pneumoniae is a common opportunistic pathogen of communityacquired and nosocomial infections in goats (Fang et al. 2004). Microbiological examination of the isolated causative bacteria and grown pink colonies on MacConckey agar resemble the results of Dubey et al. (2013). The isolated bacteria were Gram -ve, non-motile and rod-shaped, agreed with Loschko et al. (2011). The result of identification of the klebsiella spp causative agent of pneumonia in Boer goats based on biochemical tests is in agreement with Izquierdo et al., (2003), Fang et al. (2004) and Chiu et al. (2013). This result were confirmed by PCR of the gyr A gene of Klebsiella that revealed positive (+ve) result of klebsiella. The length of amplified product was 441 bps. The hematological examination showed anemia in pneumonic Boer goats that might be attributed to micro-hemorrhages and sequestration of red blood cells during disseminated microthrombosis (Gutierrez et al., 1999) or to the destruction of red blood cells by microorganism secretions (Mondal et al., 2004). Anemia could also be attributed to 
iron deficiency that could be attributed to reduction of energy and protein intake due

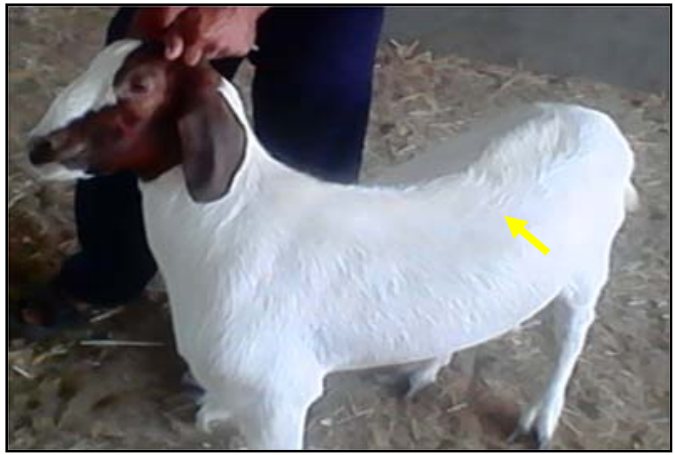

Fig. (1): Healthy Boer goat

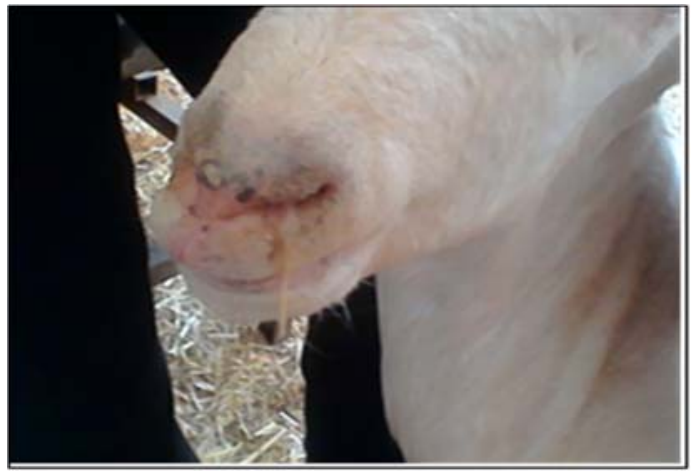

Fig (3): Mucopurulent nasal discharge with food debris of diseased pneumonic Boer goat.

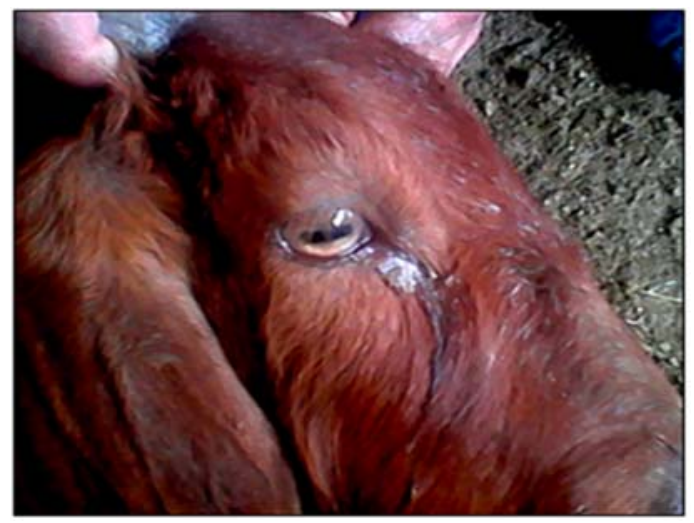

Fig (5): Ocular discharge of diseased pneumonic Boer goat.

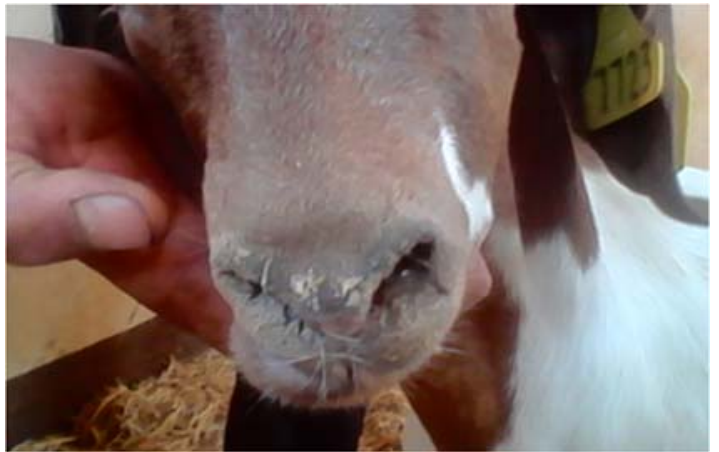

Fig. (2): Nasal discharge tinged with blood of pneumonic Boer goat.

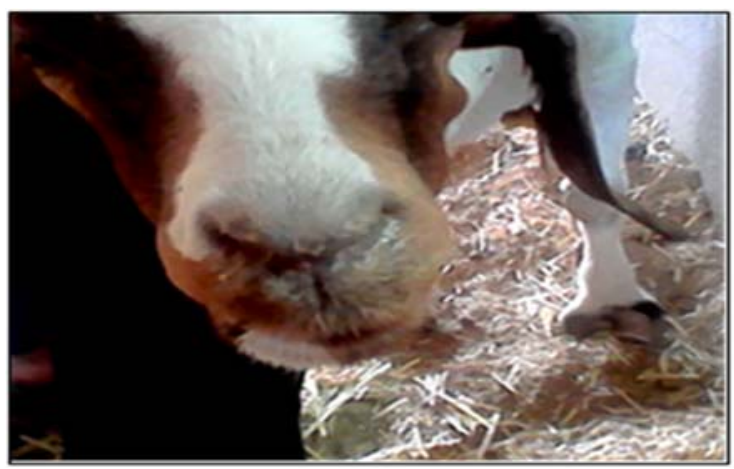

Fig (4): Nasal discharge with crusts formation around nasal orifice of pneumonic Boer goat.

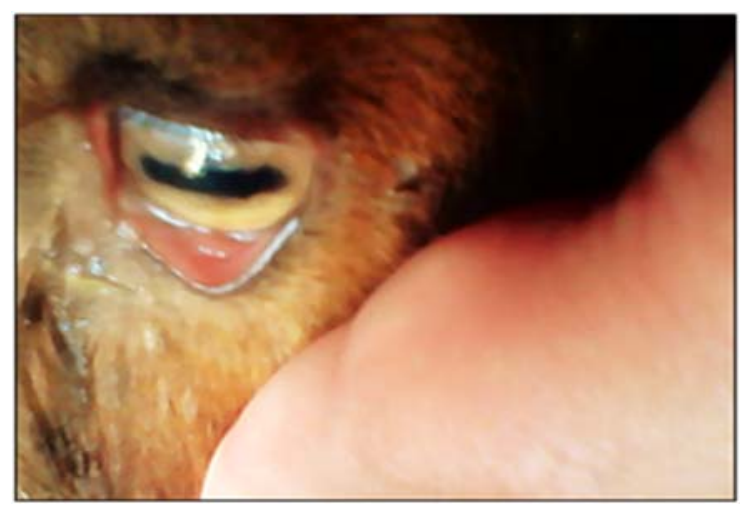

Fig (6): Redness of ocular mucus membrane of pneumonic Boer goat. 


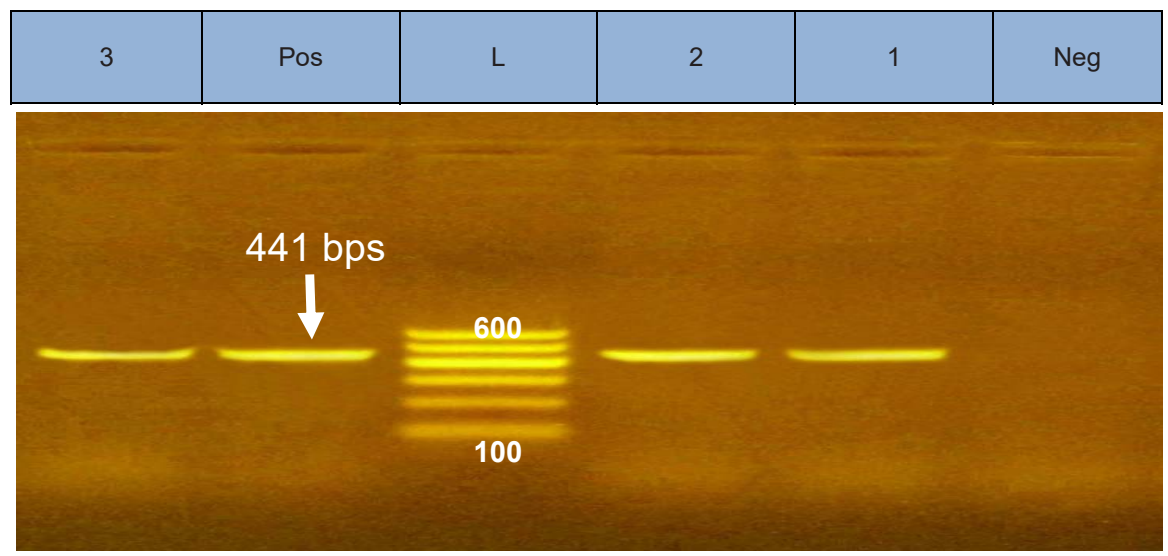

Fig (8): The result of PCR of the gyr A gene of 441 bps size of Klebsiella in the three samples of lung (1), trans-trachea (2) and nasal swab (3). The Neg= negative control

Table (1): Changes in hematology of diseased pneumonic Boer goats compared with control.

\begin{tabular}{lcccccccc}
\hline & $\begin{array}{c}\text { RBCs } \\
\left(10^{6}\right.\end{array}$ & $\begin{array}{c}\mathrm{Hb} \\
(\mathrm{gm} / \mathrm{dl})\end{array}$ & $\begin{array}{c}\text { PCV } \\
(\%)\end{array}$ & $\begin{array}{c}\text { WBCs } \\
\left(10^{3}\right.\end{array}$ & $\begin{array}{c}\text { Lymphocyte } \\
\left(10^{3} / \mu \mathrm{l}\right)\end{array}$ & $\begin{array}{c}\text { Neutrophils } \\
\left(10^{3} / \mu \mathrm{l}\right)\end{array}$ & $\begin{array}{c}\text { Monocytes } \\
\left(10^{3} / \mu \mathrm{l}\right)\end{array}$ & $\begin{array}{c}\text { Eosinophils } \\
\left(10^{3} / \mu \mathrm{l}\right)\end{array}$ \\
Groups & $/ \mu \mathrm{l})$ & & & $/ \mu \mathrm{l})$ & & & & 4.86 \\
\hline Control & 6.03 & 12.3 & 33 & 12.19 & 69.03 & 21.27 & 4.84 & \pm 0.45 \\
group & \pm 0.46 & \pm 1.23 & \pm 1.14 & \pm 1.98 & \pm 1.26 & \pm 0.89 & \pm 0.81 & 5.24 \\
Pneumonic & 4.99 & 11.12 & 28.49 & 16.55 & 63.52 & 26.02 & 4.92 & \pm 0.86 \\
group & $\pm 0.72 *$ & \pm 0.79 & \pm 4.31 & $\pm 1.67 *$ & $\pm 1.32 *$ & $\pm 1.46^{*}$ & \pm 0.58 & \\
\hline
\end{tabular}

Data are presented as means \pm S.E. (S.E. $=$ Standard error). $\quad *$ Means significantly different from control at $P<0.05$

Table (2): Changes in pulmonary function tests of diseased pneumonic Boer goats compared with control.

\begin{tabular}{lcccccc}
\hline Groups & $\mathrm{pH}$ & $\begin{array}{c}\mathrm{PCO}_{2} \\
(\mathrm{mmHg})\end{array}$ & $\begin{array}{c}\mathrm{PO}_{2} \\
(\mathrm{mmHg})\end{array}$ & $\begin{array}{c}\mathrm{tCO}_{2} \\
(\mathrm{mmol} / \mathrm{L})\end{array}$ & $\begin{array}{c}\mathrm{HCO}_{3} \\
(\mathrm{mmol} / \mathrm{L})\end{array}$ & $\begin{array}{c}\mathrm{BE} \\
(\mathrm{mmol} / \mathrm{L})\end{array}$ \\
\hline Control & 7.412 & 38.12 & 39.46 & 19.56 & 18.36 & -3.74 \\
group & \pm 0.026 & \pm 0.752 & \pm 0.616 & \pm 1.672 & \pm 1.632 & \pm 1.78 \\
Pneumonic & 7.3 & 47.18 & 37.22 & 24.83 & 23.37 & 0.31 \\
group & $\pm 0.093 *$ & $\pm 4.6 *$ & $\pm 0.97 *$ & $\pm 3.95 *$ & $\pm 3.98 *$ & $\pm 1.6 *$ \\
\hline
\end{tabular}

Data are presented as means \pm S.E. (S.E. $=$ Standard error). $\quad *$ Means significantly different from control at $P \leq 0.05$

Table (3): Serum biochemical changes of selected biochemical parameters of pneumonic Boer goats compared with control.

\begin{tabular}{lcccccccc}
\hline & \multicolumn{4}{c}{ Protein analysis } & \multicolumn{3}{c}{ liver enzymes } & \multicolumn{2}{c}{ Kidney functions } \\
Groups & $\begin{array}{c}\mathrm{TP} \\
(\mathrm{gm} / \mathrm{dl})\end{array}$ & $\begin{array}{c}\text { Albumin } \\
(\mathrm{gm} / \mathrm{dl})\end{array}$ & $\begin{array}{c}\text { Globulin } \\
(\mathrm{gm} / \mathrm{dl})\end{array}$ & $\begin{array}{c}\text { A/G } \\
\text { ratio }\end{array}$ & $\begin{array}{c}\text { ALT } \\
(\mathrm{IU} / \mathrm{L})\end{array}$ & $\begin{array}{c}\text { AST } \\
(\mathrm{IU} / \mathrm{L})\end{array}$ & $\begin{array}{c}\text { Urea } \\
(\mathrm{mg} / \mathrm{dl})\end{array}$ & $\begin{array}{c}\text { Creatinine } \\
(\mathrm{mg} / \mathrm{dl})\end{array}$ \\
\hline Control & 6.76 & 3.246 & 3.514 & 0.929 & 22.126 & 71.4 & 24.61 & 0.698 \\
group & \pm 0.17 & \pm 0.115 & \pm 0.211 & \pm 0.07 & \pm 1.521 & \pm 3.92 & \pm 2.55 & \pm 0.106 \\
Pneumonic & 6.39 & 2.46 & 3.935 & 0.626 & 35.76 & 129.06 & 37.85 & 1.476 \\
group & $\pm 0.18^{*}$ & $\pm 0.17^{* *}$ & $\pm 0.083^{*}$ & $\pm 0.045^{* *}$ & $\pm 6.6^{*}$ & $\pm 10.89^{* *}$ & $\pm 6.68^{*}$ & $\pm 0.343 *$ \\
\hline
\end{tabular}

Data are presented as means \pm S.E. (S.E. $=$ Standard error). $\quad *$ Means significantly different from control at $P<0.05$. TP $=$ total protein 
Table (4): Changes in serum protein electrophoresis and immunoglobulin (IgG and $\operatorname{IgA}$ ) of pneumonic Boer goats compared with control.

\begin{tabular}{|c|c|c|c|c|c|c|}
\hline \multirow[t]{2}{*}{ Parameters } & \multicolumn{4}{|c|}{ Protein electrophoresis } & \multicolumn{2}{|c|}{ Immunoglobulin } \\
\hline & $\begin{array}{c}\text { Alpha }(\alpha) \text { - } \\
\text { 1-globulin } \\
\text { (gm/dl) }\end{array}$ & $\begin{array}{l}\text { Alpha }(\alpha) \text { - } \\
\text { 2-globulin } \\
(\mathrm{gm} / \mathrm{dl})\end{array}$ & $\begin{array}{c}\text { Beta } \\
(\beta)- \\
\text { globulin } \\
(\mathrm{gm} / \mathrm{dl})\end{array}$ & $\begin{array}{c}\text { Gamma } \\
(\gamma)- \\
\text { globulin } \\
(\mathrm{gm} / \mathrm{dl})\end{array}$ & $\begin{array}{c}\mathrm{IgG} \\
(\mathrm{mg} / \mathrm{dl})\end{array}$ & $\underset{(\mathrm{mg} / \mathrm{dl})}{\mathrm{IgA}}$ \\
\hline Control & 0.275 & 0.589 & 0.671 & 1.979 & 1014 & 190 \\
\hline group & \pm 0.024 & \pm 0.032 & \pm 0.021 & \pm 0.165 & \pm 3.2 & \pm 5.6 \\
\hline $\begin{array}{c}\text { Pneumonic } \\
\text { group }\end{array}$ & $\begin{array}{l}0.244 \\
\pm 0.03\end{array}$ & $\begin{array}{c}0.621 \\
\pm 0.115 \\
\end{array}$ & $\begin{array}{c}0.675 \\
\pm 0.062 \\
\end{array}$ & $\begin{array}{c}2.396 \\
\pm 0.167 * \\
\end{array}$ & $\begin{array}{c}1074 \\
\pm 14 * \\
\end{array}$ & $\begin{array}{c}213.2 \\
\pm 11.8 *\end{array}$ \\
\hline
\end{tabular}

Table (5): Changes in serum minerals of pneumonic group compared with control group.

\begin{tabular}{|c|c|c|c|c|c|c|c|}
\hline $\begin{array}{l}\text { Parameters } \\
\text { Groups }\end{array}$ & $\begin{array}{c}\mathrm{Ca} \\
(\mathrm{mg} / \mathrm{dl})\end{array}$ & $\begin{array}{c}\mathrm{P} \\
(\mathrm{mg} / \mathrm{dl})\end{array}$ & $\begin{array}{c}\mathrm{Fe} \\
(\mathrm{mg} / \mathrm{dl})\end{array}$ & $\begin{array}{c}\mathrm{Mg} \\
(\mathrm{mmol} / \mathrm{L})\end{array}$ & $\begin{array}{c}\mathrm{Na} \\
(\mathrm{mmol} / \mathrm{L})\end{array}$ & $\begin{array}{c}\mathrm{K} \\
(\mathrm{mmol} / \mathrm{L})\end{array}$ & $\begin{array}{c}\mathrm{Cl} \\
(\mathrm{mmol} / \mathrm{L})\end{array}$ \\
\hline Control & 8.574 & 4.22 & 0.63 & 1.693 & 144.6 & 4.3 & 97.62 \\
\hline group & \pm 0.165 & \pm 0.74 & \pm 0.088 & \pm 0.086 & \pm 1.52 & \pm 0.12 & \pm 1.98 \\
\hline Pneumonic & 7.166 & 6.62 & 0.42 & 1.059 & 141.7 & 5.32 & 83.43 \\
\hline group & $\pm 0.92 *$ & $\pm 1.15 *$ & $\pm 0.04 *$ & $\pm 0.322 *$ & \pm 2.81 & $\pm 0.447 *$ & $\pm 7.64 *$ \\
\hline
\end{tabular}

to anorexia observed with pneumonia or sequestration of iron in bone marrow macrophages and hepatocytes during infection, thus become unavailable for utilization in hemoglobin synthesis leading to inhibition of erythropoiesis (Mosa, 2000). The significant increase of WBCs and neutrophils might be attributed to inflammatory lesions and presence of bacterial infection (Abou El-Gheit, 2000). On the other hand, the significant decrease of lymphocytes might be attributed to the stimulation of adrenal gland during stress with the tissue invaded by bacterial toxins (Abou El-Gheit, 2000). The changes of pulmonary function tests including significantly decreased $\mathrm{pH}$ and $\mathrm{PO}_{2}$ and significantly increased $\mathrm{PCO} 2, \mathrm{tCO} 2, \mathrm{HCO} 3$ and $\mathrm{BE}$, these results ressemble the results recorded by Abd El-Raof and Hassan (1999), Aslan et al., (2002) and Nagy et al., (2006) in calves affected with pneumonia. These results might be attributed to the pathological actions of microorganisms or its toxins such as lipopolysaccharide (Ghanem et al., 2012) which affecting on blood gas exchange and blood $\mathrm{pH}$ that decreased to the acid side resulting in acidaemia (Karademir et al., 1999). While the decrease in $\mathrm{PO}_{2}$ (hypoxia) with increase in $\mathrm{PCO}_{2}$ (hypercapenia), $\mathrm{HCO}_{3}$ and $\mathrm{tCO}_{2}$ might be attributed to shallow rapid respiration (polypenia) suggesting that the breath rhythm and intensity were insufficient to eliminate $\mathrm{CO}_{2}$ and supply $\mathrm{O}_{2}$ and impaired pulmonary function or might be result from hypoventilation, diffusion impairment, ventilation-perfusion mismatch (Pugh, 2002 and Smith and Sherman, 2009). The drop in $\mathrm{pH}$ could be attributed to the continuity of metabolism in the form of oxygen consumption as a result of anaerobic metabolism with generation of carbon dioxide in the tricarboxylic acid cycles or accumulation of lactic acid due to glycolysis this during the period from sampling to analysis. Also the elevated $\mathrm{tCO}_{2}$ and $\mathrm{PCO}_{2}$ might be attributed to the aerobic metabolism that produces $\mathrm{CO}_{2}$, and as a result increase the level of $\mathrm{HCO}_{3}$ which actually accounts for approximately $95 \%$ of the measured $\mathrm{tCO}_{2}$. Decrease $\mathrm{PO} 2$ besides the disturbance of gas exchanges it might be attributed to the consumption of oxygen 
during metabolism due to elevated WBCs and anemia this may be continued during the period from sampling to analysis that may reach two or three hours (Hussein and Aamer, 2013). The hypoproteinemia could be attributed to certain bacteria or bacterial toxins that increase capillary permeability and permit escape of plasma proteins in tissues so osmotic pressure of proteins is increased in the tissue fluids and at the same time decreased in the blood (Omran et al., 2005). The hypoalbuminemia could be attributed to anorexia associated with pneumonia and inability of liver to synthesize protein (El-Seidy et al., 2003). The hyperglobulinemia might be due to the stimulation of immune system by the infectious agent (Abd El-Raof and Hassan, 1999). The higher level of IgG and IgA could be attributed to the stimulation of humeral immune system by the infectious agent (Gaber et al., 2000) who attributed increase gamma $\gamma$-globulin and immunoglobulin to increased antibodies production in response to antigenic stimulation caused by the microorganisms. The significant increase of serum enzymes AST and ALT levels agreed with Abou ElGheit (2000) and Saleh and Allam (2014). This might be attributed to the degenerative and necrotic changes in different internal organs accompanied the formation of pulmonary lesion due to bacterial infection and its toxin. The increase in urea concentration could be explained by the accelerated catabolism of body protein to compensate for anorexia and could result as a response to infection while the increase in serum creatinine might be attributed to kidney dysfunction after infection (Radostits et al., 2000). The changes of serum minerals might be attributed to infectious diseases that lead to anorexia and reduction of blood calcium and increased phosphorus concentrations. There is a reciprocal relationship between $\mathrm{P}$ and $\mathrm{Ca}$ in the serum and hyperphosphatemia leads to a reciprocal reduction in the serum ionized calcium concentration because of the mass law interactions between phosphate and calcium ions (Kaneko et al., 2008). The hypochloremia with hyperkalemia might be attributed to the hyperpyrexia in the acute course of the disease and metastatic infection of liver and kidneys resulting in hepatic and renal dysfunction (Novert, 2004). High serum potassium concentrations could be seen in respiratory diseases particularly if acidosis is present because $\mathrm{H}+$ ions accumulated in the extracellular fluid is exchanging with potassium present in the intracellular fluid leading to hyperkalemia (Kaneko et al., 2008). The decreased Fe could be attributed to reduction of energy and protein intake or sequestration of iron in bone marrow macrophages and hepatocytes during infection, making it unavailable for erythropiosis (Kaneko et al., 2008).

\section{CONCLUSION}

According to the results of this study we can concluded that, pneumonia due to klebsiella pneumoniae that isolated from respiratory tract of pneumonic Boer goats causes alteration of pulmonary function tests and hematobiochemical parameters that we can be used as a diagnostic tools for pneumonia in Boer goats.

\section{ACKNOWLEDGMWNT}

Special Thanks for Center of Excellence in Scientific Research (CESR), fac. of vet. Med. Benha Univ. that funded by management supporting excellence (MSE) and Benha University.

\section{REFERENCES}

Abd El-Raof, Y.M., Hassan, H.Y. 1999. Ultrasonography and other aids for calf pneumonia diagnosis. $5^{\text {th }}$ Sci. Cong. Egy. Soci. Cattle Dis. Assuit, Egypt.

Abou El-Gheit, A.I.A. 2000. "Liver and kidney functions in healthy and diseased small ruminant", M.V.Sc. thesis Faculty of Veterinary Medicine, Zagazig University. 
Ackermann, M. R., Derscheid, R., Roth, J. A. 2010. Innate immunology of bovine respiratory disease. Vet. Clin. North Am. Food Anim. Pract., 26:215-228.

Aslan, V., Maden, M., Erganis, O., Birdane, F.M., and Corlu, M., 2002. Clinical efficacy of florfenicol in the treatment of calf respiratory tract infections, Veterinary Quarterly, 24(1):35-39.

Autio, T., Pohjanvirta, T., Holopainen, R., Rikula, U., Pentikainen, J., Huovilainen, A., Rusanen, H., Soveri, T., Sihvonen, L., Pelkonen, S. 2007. Etiology of respiratory disease in non-vaccinated, non-medicated calves in rearing herds. Veterinary Microbiology, 119(2-4):256265.

Batavani, R. A., Ansari, M. H. Asri, S. 2006. Concentrations of serum total protein and protein fractions during diestrus and pregnancy in Makuii ewes. Comp Clin. Pathol.15:227-230.

Brisse, S., and Verhoef, J. 2001. Phylogenetic diversity of Klebsiella pneumoniae and Klebsiella oxytoca clinical isolates revealed by randomly amplified polymorphic DNA, gyrA and parC gene sequencing and automated ribo typing. Int J Syst Evol Microbiol. 51:915-924.

Bruere, A.N., West, D.M., Ridler, A.L. 2002. Enzootic Pneumonia. In: The Sheep: Health Disease and Production: Written for Veterinarians and Farmers, West, D.M., Bruere, A.N., and Ridler, A.L. (Eds.). $2^{\text {nd }}$ Ed. Vet. Continuing Education, Massey University, Palmerston North, New Zealand, pp: 100-108.

Carter, G.R. 1990. Diagnosis of hemorrhagic septicemia. Veterinary diagnostic bacteriology, a manual of laboratory procedures for selected diseases of livestock. Animal Production and Health Paper (81), Rome, FAO.

Chiu, S., Wu, T., Chuang, Y., Lin, J., Fung, C., Lu, P., Wang, J., Wang, L., Siu, K., Yeh, K. 2013. National surveillance study on carbapenem Non-susceptible Klebsiella pneumoniae in Taiwan: the emergence and rapid dissemination of $\mathrm{kpc}-2$ carbapenemase. Plos One. 8(7):1-7.

Dubey, D., Raza, F., Sawhney, A., Pandey, A. 2013. Klebsiella pneumoniae renal abscess syndrome: a rare case with metastatic involvement of lungs, eye, and brain. Case Reports in Infectious Disease, pp. 1-3.

El-Seidy, I.A., Koratum, K.M., Rafaat, M. 2003. Therapeutic effect of florfenicol against respiratory infection in sheep. Egypt. J. Comp. Path. \& Clinic. Path., 16(10): 30- 42.

Erasmus, J.A. 2000. Adaptation to various environments and resistance to disease of the improved Boer goat. Small Ruminant Research. 36, Pp: 179-187.

Fang, C.T., Chuang, Y.P., Shun, C.T., Chang, S.C., Wang, J.T. 2004. A novel virulence gene in $K$. pneumoniae strains causing primary liver abscess and septic metastatic complications. J. Exp. Med. 199, Pp: 697-705.

Feldman, B.F., Zinkl, J.C., Jain, N.C. 2000. "Schalm's Veterinary Hematology", $5^{\text {th }}$ Ed. Lippincott Williams \& Wilkins, Philadelphia, London.

Gaber, A.S., Mohamed, O.M., Samy, A.M. and El-Sayed, A.F.M. 2000. Serological and biochemical changes in sheep sera infected with either parainfluenza-3 (PI3) or infectious bovine rhinotracheitis (IBR) viruses. Egypt. J. Comp. Path \& Clinc. Path., 13(1):134-143.

Ghanem, M. M., Hubbs, A., Nath, J. 2012. Preliminary study on the effect of pulmonary inflammation mediated by lipopolysaccharide endotoxins on cytochrome P4501A1 (CYP1A1) induction in sheep. Proceedings of the $5^{\text {th }}$ Scientific Conference of Animal Wealth Research in the Middle East and North Africa, Faculty of Agriculture, Cairo University, Giza, Egypt.

Gutierrez, C., Rodriguez, J.L., Montoya, J.A., Fernandez, A. 1999. Clinico-pathologica and haematological findings in goat kids experimentally infected simultaneously with Mycoplasma mycoides subsp-capri and Mycoplasma mycoides subsp. mycoides (large colony-type). Small Ruminant Research, 31:187-192.

Henrik, C. 1994. A textbook of Methods in Practical Laboratory Bacteriology. Chapter (5): The Use of ELISA in Bacteriology, pp. 45-50.

Hussein, H.A., Aamer, A.A. 2013. Influence of different storage times and temperatures on blood gas and acid-base balance in ovine venous blood. Open Veterinary Journal, 3(1):1-7. 
Izquierdo, L., Merino, S., Regue, M., Rodriguez, F., Tomas, J. 2003. Synthesis of a Klebsiella pneumoniae $\mathrm{O}$ antigen hetero-polysaccharide $(\mathrm{O} 12)$ requires an ABC 2 transporter. J. Bacteriol. 185: 1634-1641.

Kaneko, J.J., Harvey, J.W., Bruss, M.L. 2008. Clinical biochemistry of domestic animals, $6^{\text {th }}$ Ed. Academic Press, London, pp. 117-138.

Karademir, B., Saatci, M., Celebi, F., Erdoğan, H.M., Aksoy, A.R. 1999. Kapali ahir sartlarinda barindirilan sigirların venoz Kan gazlari degerleri. Kafkas. Univ. Vet. Fak. Derg. 5:155-159.

Kathryn, A.G. 2006. Pneumonia and pleurisy in sheep: Studies of prevalence, risk factors, vaccine efficacy and economic i mpact. A thesis presented in partial fulfillment of the requirements for the degree of Doctor of Philosophy at Massey University, Palmerston North New Zealand.

Kumar, A., Rahal, A., Chakraborty, S., Verma, A. K., Dhama, K. 2014. "Mycoplasma agalactiae, an etiological agent of contagious agalactia in small ruminantsa Review," Vet. Medicine International, 13 pages.

Loschko, J., Heink, S., Hackl, D., Dudziak, D., and Reindl, W., Korn, T., Krug, A.B. 2011. Antigen targeting to plasmacytoid dendritic cells via Siglec-H inhibits the cell-dependent autoimmunity. J. Immunol., 187:6346-6356.

MacFaddin, J.F. 2000. Biochemical Tests for Identification of Medical Bacteria. $3^{\text {rd }}$ Ed. Lippincott, New York.

Mondal, D., Pramanik, A.K., and Basak, D.K. 2004. Clinico-haematology and pathology of caprine mycoplasmal pneumonia in rain fed tropics of West Bengal. Small Ruminant Research 51: 285-295.

Mosa, Y.B. 2000. Investigation of respiratory problems in calves. M.V.Sc. thesis Fac. Vet. Med. Zagazig University.
Nagy, O., Seidel, H., Paulikova, I., Mudron, P., Kovac, G. 2006. Use of blood gases and lactic acid analyses in diagnosis and prognosis of respiratory diseases in calves. Bull. Vet. Inst. Pulawy, 50:149152.

Novert, M.H. 2004. Bacteriological and mycoplasmal studies on lung infections in newly born calves. J. Egypt. Vet. Med. Assoc., 62(4):189-194.

Omran, H., Abdel-Azim, A.M., Kodary, M. 2005. Some hematological and biochemical alterations associating clinical pneumonia in Friesian calves with trials of treatment. Present at the $4^{\text {th }}$ Int .Sci. Conf. in Mansoura, Egypt.

Pugh, D.G. 2002. A Text Book of Sheep and Goat Medicine. $1^{\text {st }}$ Edition, W.B. Saunders, USA.

Radostits, O.M., Gay, C.C., Blood, D.C., Hinchcliff, K.W. 2000. "Veterinary Medicine", $9^{\text {th }}$ (ed.), W.H. Saunders Co. LTD. London, New York, Philadelphia, Sydney, printed in China.

Sadeghian, S., Dezfouli, M.R.M., Kojouri, G.A., Bazargani, T.T., Tavasoli, A. 2011. Pasteurella multocida pneumonic infection in goat: Hematological, biochemical, clinical and pathological studies. Small Ruminant Research, 100, 189-194.

Saleh, N.S., Allam, T.S. 2014. Pneumonia in Sheep: Bacteriological and Clinicopathological Studies. American J. of Res. Commun., 2(11):70-88.

Smith, M.C., Sherman, D.M. 2009. A textbook of; Goat Medicine, $2^{\text {nd }}$ Edition. Editorial Office, 2121 State Avenue, Ames, Iowa 50014-8300, USA. Set in 10/12 pt Palatino by SNP Best-set Typesetter Ltd., Hong Kong Printed in Singapore. pp. 339-381.

Zaghawa, A., Hassan, H., El-Sify, A. 2010. Clinical and Etiological study on respiratory affections of sheep. Minufiya Veterinary Journal, 7(1):93-103. 